\title{
Claims to legitimate authority and discursive attacks
}

We don't believe in the authorities anymore. When you say ... 'there, that's the new administrator, everyone may clap but with a certain mockery ...' Him also, what is he going to do? (Peasant Union Member (no. 151) 2010)

We could wonder about the role of that whispered language within the political system of unanimity. It is, to my mind, a way of softening the overwhelming and restrictive official language in order to make it more bearable; it is an antidote. Irony and humour are the weapons of the powerless in the face of arbitrary ruling ... We can also see in it a runaway reaction ... But I think that it is more just to consider derision as a consciousness-raising exercise, and as a consequence, a way of social contestation. (Toulabor 2008: 112)

[I]t is in fact more plausible to contend that so far as the realm of ideology is concerned, no social order seems inevitable ... the imaginative capacity of subordinate groups to reverse and/or negate dominant ideologies is so widespread - if not universal - that it might be considered part and parcel of their standard cultural and religious equipment. (Scott 1985: 331)

\section{Statebuilders and state-recipients, a pose}

A uthority is generally claimed with an underlying morality. Peacebuilding, and the reconstruction of state authority, is deployed as the best solution to the problems of war, authoritarianism and poverty (Chandler 2010a: 1). In Eastern DRC this authority claim has materialised as a discourse of protection and social change. Against this discursive construction, mockery, denigration and slandering operate as an intentional mechanism to deny the legitimacy and authority of peacebuilding. Resistance is not necessarily against the ideals of the good state, democracy, development and peace, but to the fact that neither protection nor social change is being delivered. By using the same language of peacebuilding, referring to the state, democracy, peace and development, the discourse is used as a platform for advancing alternative agendas. Peacebuilding discourse is not only resisted, but also subverted. 


\section{Claims to authority and discursive attacks}

The three quotes above capture three ways in which discursive resistance takes place in the DRC. First, the union representative articulates what Scott calls the 'pose' (the roles that the powerless and the powerful adopt towards each other). The act of not clapping at a politician in a parade would be an act of denial of his/her share of pomp and deference, and with that, a delegitimisation of his/her authority. What Scott and this union representative convey is that resistance does not often operate as a direct defiance in front of authority. Generally, one may clap at the parade, but express reticence and discontent somewhere else. Secondly, resistance is to be found in how Congolese non-elites judge authorities from their lived experience, even if this is shown only in the 'whispered language' far from the hype of a politician's parade. Thirdly, discursive resistance illustrates that criticism is a form of resistance to the unanimity that peacebuilding claims, subverting the official discourse and revealing dissent.

Ideals constitute a platform on which both power and resistance operate. The claims to construct the good state, bring democracy, development and peace, become long-term claims on which peacebuilders and state-makers legitimise their interventions and demand consent. They are also discursive formulas to justify 'failure'. As John Heathershaw argues, the 'survival' of peacebuilding is due to the resilience of its discourse. Seen from the goals of transforming society through the construction of a positive peace, democracy and state-society relations, peacebuilding 'fails', and becomes a 'simulacra' of its own discourse (Heathershaw 2008). This captures the situation in the DRC, where, despite the continuation of war, the increasing authoritarianism and the deterioration of living conditions, peacebuilding survives on its discourse as a long-term claim to rearrange society under a particular worldview. ${ }^{1}$ Simultaneously, these ideals become a way to hold statebuilders to account, to voice discontent and elaborate a vision of how things should be.

In Scottian terms, these ideals correspond to the battleground on which elite and non-elites' public and hidden transcripts are enacted. Although, as Heathershaw (2008) argues, peacebuilding contexts generate multiple transcripts, these two serve as a standpoint to observe how authority claims are laid out and how they are denied or mitigated. The dynamics of claiming authority while justifying and externalising failure turn peacebuilding's public transcript into what Barrington Moore calls the moral authority of suffering (1978: Ch. 2). Peacebuilding's discourse is projected with a sense of inevitability and unanimity, demanding consent, despite continuous armed conflict and deteriorating living conditions. These conditions, however, generate criticisms and political alternatives.

Although the hidden transcript cannot be simplistically seen as an arena of freedom, it provides a safer audience among relative equals. ${ }^{2}$ The public transcript has several functions, including: concealment (hiding the nasty aspects 
of power and elites' disagreement), unanimity (giving a sense of agreement between elites and non-elites and denying dissent), euphemism and stigma (beautifying power and uglifying dissent) and public parade (dramatising the grandeur of power) (Scott 1990: 45-66). These functions are visible in that peacebuilding's claim to authority is done by projecting an image of unanimity and grandeur. It also operates as concealment and stigma, as a way of externalising blame for failure and as a way to stigmatise dissent. They create a pose, illustrating that authority claims generate mutual constraints of behaviour on both authorities and subordinate classes and that consent is not 'the whole story' (Scott 1990: 2). In the DRC, although counterdiscourses are part of the public domain, they are constructed in the safety of anonymity.

The chapter will proceed as follows. Firstly, it analyses peacebuilding's public transcript and its construction of a moral authority. Secondly, it analyses non-elites' hidden transcript. This latter part will be done in two sections, the first of which analyses mockery, denigration and slandering as ways of negating legitimacy and demanding accountability. These are illustrative of a more direct engagement with an authority claim and represent claimregarding acts. The second analyses the redefinition of standard peacebuilding vocabulary, such as the 'state', 'democracy', 'peace' and 'development', where the creation of alternative political agendas is particularly visible. These are illustrative of self-regarding acts in so far as they subvert peacebuilding goals by simultaneously voicing how they are not being achieved and advancing alternative political agendas. Taking these factors together offers non-elites what Certeau sees as the 'opportunity' of transforming "belief" into "mistrust", into "suspicion", and indeed "denunciation" [...] to manipulate politically what serves as circular and objectless credibility for political life itself' (1984: 189).

\section{Elite claims and the moral authority of suffering}

For Moore, authority implied obedience to the social arrangements by which 'some human beings extract an economic surplus from other human beings and turn them into culture' (1978: 17). In turn, 'pain and suffering [become] to a degree morally desirable [...] unavoidable or even inevitable' (Moore 1978: 80). Although Moore theorised this moral authority as the basis for obedience to some of the most tyrannical systems, in the DRC this moral authority enables elites to demand obedience and justify the continuation of war on the basis that they can provide the goods of peacebuilding, even if not right now.

The discordance between discourse and practice gives peacebuilding the moral justification to exercise its agenda and its power. The sense of inevitability 


\section{Claims to authority and discursive attacks}

and necessity with which statebuilding is deployed serves two main functions: as a discourse of legitimacy and a justification for failure. Firstly, it has the capacity to create a shared vocabulary and meaning on which to justify authority. Subsequent claims attached to the position of authority (i.e. extracting taxes, negotiating international agreements, allowing foreign investments or articulating military operations) are premised on peacebuilding actors delivering the good state, democracy, development and peace. Secondly, the public transcript functions as a projection of state-making as necessary and inevitable in order to demand consent. Its failures, which are explained in previous chapters, relate to the continuation of conflict, worsening of living conditions, a militarisation of social and political life and increasing authoritarianism, and are externalised in a dramatisation of power doing all it can against an extremely adverse context. This section examines these two functions of authority claims and the justification of failure found in two main actors: the MONUC/MONUSCO and the Government.

\section{MONUC/MONUSCO}

MONUC was set up with the legalistic wording of the UN Charter for the maintenance of international peace and security, but this was in the spirit of addressing the 'well-being and security of the population' as well as the 'adverse impact of the conflict on the human rights situation' (UN Security Council 1999: 2). Similarly, Resolution 1925, which changed MONUC to MONUSCO, established its priorities as: civilian protection, peace stabilisation and consolidation, and restoration of state authority (UN Security Council 2010). More than ever before, Resolution 1925 put the responsibility for peace and order on the Congolese Government, while defining the UN mission as an external supportive actor, primarily concerned with civilian protection and political oversight.

The success in civilian protection nevertheless remains limited. As seen in the previous chapter, the same peace agreements that have brought about a relative truce have legitimised armed actors and armed struggle as a vehicle for political power. Many of these agreements are at the basis of an almost blanket impunity operating in the DRC. Peacebuilding provides, in this case, the capacity to claim authority while externalising responsibility. One of the most criticised cases of neglect was the massacre in Kiwanja in 2008. The CNDP attacked the town, killing approximately 150 people 'half a mile' from the MONUC's base, hosting 138 peacekeepers (Human Rights Watch 2008: 1). The population protested against these events and the failure to protect them by throwing stones and Molotov cocktails at the UN compound in Goma (BBC 2008; CNN 2008; MONUC Civil Affairs Officer (no. 14) 2009; OCHA - MONUC 2008). For MONUC Civil Affairs, easing the intensity and persistence of these protests and criticisms 
is about the population understanding what the UN mandate is about and its limits. As an officer in Kinshasa stated:

This is what we try to do now because there was lots of criticism towards MONUC from civil society on protection issues. Hopefully that is why we also have the logistic part as one of our pillars. We try to take them [civil society organisations] with us as much as we can on the ground, so that they see the situation on the ground and they can also inform the population and see how we can better protect people. We do that with the Government, so that they take responsibility and they don't just sit and criticise. (MONUC Civil Affairs Officer (no. 1) 2009)

The fact that protection depends on Congolese actors understanding 'the situation on the ground' and providing solutions reveals the dynamics of a discourse of legitimacy in the face of failure. But, contrary to the overall aim stated in the quote, criticism has not gone away.

In fact, a substantial review took place at the end of 2012, just after the crisis of the M-23 movement. A new 'robust mandate' was put in place, authorising the use of force for the purpose of attacking armed groups, together with a new political strategy aimed at addressing conflicts over land, corruption and impunity. This was due not only to pressures in the UN Security Council, whose 'P-3 were pushing for a quick exit strategy' (MONUSCO Officer (no. 166) 2014), but also to a realisation of previous mistakes in which, as a MONUSCO officer acknowledged, 'MONUSCO had been supporting a predatory state' (MONUSCO Officer (no. 166) 2014; MONUSCO Officer (no. 190) 2014). This illustrates the capacity for self-criticism and that reviews are done towards improvement. But the fact that responsibility for the continuation of war and statebuilding is placed on the Government allows for the portrayal of MONUSCO as a neutral third party mediating between political and military authorities and the civilian population, while establishing a rationale for its presence and command. The factual veracity of these claims is not as important as what they represent for the capacity to define the problem and the solution. For instance, speaking of the success of the IB that was authorised by the UN Security Council in response to the M-23, a MONUSCO officer indicated that: "The UN is claiming that we won, but it is the FARDC that did most of the fighting, the IB was only supporting. The M-23 was defeated because it didn't have Rwandan support, Western FARDC commanders were brought in and the Eastern ones were taken back to Kinshasa, troops were well supplied' (MONUSCO Officer (no. 166) 2014). Still the public discourse is that lack of a proper army is the major obstacle for peace and one main reason for the UN presence.

Similarly, the new International Support Strategy for Security and Stabilisation, drafted in 2013, is based on errors committed by MONUC and MONUSCO in previous years (ISSSS 2013). Whereas this strategy had been operating as 


\section{Claims to authority and discursive attacks}

counter-insurgency (clearing roads and points where armed groups operated, implanting socio-economic recovery and building state infrastructure), it is now focused on organising local community dialogues to make authorities more accountable (MONUSCO Officer (no. 163) 2014). The ultimate aim of this strategy is to build relations between state and society on trust, transparency and due process. Failed strategies constitute in themselves an argument to reproduce a discourse of authority and external blame.

The need to reconstruct how society works highlights the hidden transcript of the UN in the DRC and its underlying image of the DRC as dysfunctional. This dysfunctionality is seen in statements like 'elections are still tribal here' (MONUSCO Political Affairs Officer (no. 45) 2010); 'the Government does not even have figures of its own population' (MONUSCO Civil Affairs Officer (no. 158) 2011); 'there is no sense of progress' (MONUSCO Electoral Division Officer 2010; MONUSCO Political Affairs Officer (no. 45) 2010; MONUSCO Political Affairs Officer (no. 46) 2010); 'here, there are no political parties or real civil society' (MONUC Political Affairs Officer (no. 7) 2009). ${ }^{3}$ In several informal conversations with UN officials, UN agency members and other international representatives there is a commonly held view that civil society is a collection of individuals who attempt to access international money by acquiring the vocabulary that funding bodies and international organisations want. ${ }^{4}$ In a similar way that popular classes negate the existence of the state, creating an image of what the state should be, elites' negation of civil society is a way to de-legitimise 'civil society'. This works as a hidden transcript, redressing international actors and demonising those who, in the public transcript, were the heroes of government and peacebuilding policies. Furthermore, underlying this criticism there is an assumption about the Congolese being corrupt, not really interested in undertaking such noble aims as 'democracy' and 'good governance', but instead using the vocabulary to access international funding.

A MONUC officer, for instance, affirmed:

We are dealing with people who are helpless ... The mass of the people in this country are illiterate ... there are no real political parties here, we are trying to build this country from scratch, there is no real civil society ... it is in a state of infancy. (MONUC Political Affairs Officer (no. 7) 2009)

Portraying the Congolese as helpless only justifies the strategies of the intervention. Other common tags used by MONUC/MONUSCO and diplomatic officials in interviews and informal conversations were 'corrupt', 'lazy', 'opportunistic', 'selfish' and 'backward'. This implies that it is the fault of the Congolese, both elites and non-elites, for being in the situation they are in. As previously noted, whether these analyses are accurate or not does not reveal their primary 
function, which is to reaffirm the rightness of the strategies, and the difficulty of the task.

\section{Government}

The vocabulary of the state as an engine and receptacle of peace, democracy and development is deployed in a similar manner by the Government. Peacebuilding, with its state-making ethos, provides a model to mirror the Government's public image and justify action. Electoral campaigns have illustrated peacebuilding vocabulary very clearly. The programme of each political party has revolved around its capacity to restore state authority and bring peace, democracy and development. For instance, Joseph Kabila based his 2006 campaign on the 'five pledges' (cinq chantiers) referring to development (Nzazi Mabidi 2006). This was pushed forward in the 2011 elections with the 'Revolution of modernity' (Na Raïs 2011). The programme is based on the promise of development, to make the DRC an emergent country by 2030 and a world power to join the BRICS countries by 2060 (Na Raïs 2011: 2).

Kabila's media platforms also revolve around the cohesiveness of state authority. Kabila TV, which is linked to the presidential website and his own private media platform, DigitalCongo, which includes a TV channel and a news website, both display a focus on developmental projects and on the official and solemn acts of Kabila as president (Kabila TV 2012; Multimedia Congo s.p.r.l. 2012). State unity, development and peace have been Kabila's discourse drivers. Not only do these resonate with people's political aspirations, they have also been presented as arguments to ask the UN to leave. In December 2009, in a conference broadcast by the Congolese National Radio and Television (RTNC), Kabila emphasised 'the good relationship between the UN and the Congolese Government' but stated that there should be 'a plan of progressive UN retreat and disengagement' based 'on the net improvement of the security situation in the Eastern part of the country' (RTNC 2009). The unnecessary presence of the UN has been a regular argument of the Government, up until the point where Kabila rejected the support of MONUSCO in its 2015 attacks against the FDLR (Anon 2015; Radio Okapi 2015). The image that the Government projects reflects the broad foundations of peacebuilding discourse. These include the cohesiveness of state authority in being able to maintain its territory, to secure its population, to be the democratically elected representatives and to have an economic development and modernisation plan. For the DRC Government, peace, democracy and development operate as a shared vocabulary on which to premise legitimate state authority.

The responsibility for not achieving these goals is a matter of blame exchange. For instance, when the complaints heard from MONUC/MONUSCO officials and those of the population were put to a few Government 


\section{Claims to authority and discursive attacks}

representatives, the response was usually to blame the "international community'. Speaking about the M-23 rebellion, an MP and customary chief stated:

The occupation of Goma was done by the RPF [Rwandan Patriotic Front], not the M-23, they have entered through the Great Barrier [formal border] with no issues, under the visible sight of the UN. What are they [UN/Internationals] doing if not allowing that Congo is maintained as a subordinate of Rwanda and their allies? (Masisi MP 2 2014)

Speaking more broadly, another representative stated:

The DRC needs social democracy but it is not possible because of lack of investment and lack of financial means. The DRC is asphyxiated because the policy from the big powers is 'you pay us first before we give you the money' ... also everyone is having a piece of the cake here. The US and France take the petrol, the US and Belgium take the cobalt, Germany operates in the Katanga mining, the gold is taken by Canada and the UK and a bit by the US, diamonds are taken by Israel, Holland and South Africa. I have no problem with investment in resources, but in the context of a neocolonial model, there is no hope for the Congolese. (Government Representative (no. 31) 2009)

The narrative is not simply one of political elites absolving themselves of responsibility, but of pointing out the constraints they suffer to fulfil their promises to their electorate. Similarly, for a member of the North Kivu National Assembly, the DRC was a place for everyone to get rich through programmes of development and peacebuilding. He complained that MONUC's vehicles always seemed to be parked and that they were not travelling to the interior of the country. He added:

We don't understand MONUC's politics. After 2005, they are there, we see them patrolling with the helicopters during the night, if the enemy is in the skies, we don't know ... they come for example to support elections, or giving some bureaucratic support to the Government, but regarding security, in comparison with the arsenal they have, the weapons ... if we had such capacity all the problems will be finished by now. (North Kivu Provincial Assembly representative 2010)

The image this representative presents is of the Congolese being victimised while not having the necessary capacity to face the problem. Peacebuilding's discourse is enacted as a public transcript that serves as a tool to legitimise action and inaction and to externalise blame. A common vocabulary is created around idealised versions of the state, democracy, development and peace that serve as a platform for authority claims. In the view of Congolese officials this is not an appropriation of "international" vocabulary but represents their own aspirations. Thus 'democracy', 'decentralisation' and many strategies for reform are the initiative of the Congolese Government, and not of the 'international community' (Beni MP 2010; DRC Government Advisor 2013; Masisi MP 2 2014; Ministry of Planning Representative 2010; STAREC Representative 2 2014; 
Uvira MP 2011). Yet, as long as they remain a discourse, these are better seen as claims which have embedded symbolic and material demands on Congolese subordinate classes. There is a demand for recognition, consent and legitimation, in spite of the reality of hardship. The creation of ideals, the justification of power on moral grounds and the normative commitments deployed with the peacebuilding process are part of the tools that authority uses. Conversely, these are turned into weapons of de-legitimisation and into a platform from which to advance alternative agendas.

\section{The denial of legitimacy}

If peacebuilding operates as a claim to legitimacy and consent, and resistance is defined by the denial of these claims, what follows is that de-legitimisation and disobedience should be seen as primary areas of resistance. For Scott, it is here that the hidden transcript develops. Mocking, denigrating and slandering authority, in the claims both of MONUC/MONUSCO and of the Government, are widely used tools. Although these discourses take place in the open, they are done through the safety of privacy or anonymity of the crowd. They are not necessarily hidden, so much as they are non-confrontational.

Toulabor's quote above argues that humour and derision are often used as methods for confronting the established social order and, as such, should be seen within a sphere of social contestation. Mockery, denigration and slander constitute a form of resistance in that they configure a pattern of action that denies the legitimacy of power, turning its claims to authority into an exercise of domination. That is, if power is justified by its capacity to create the good state that can deliver peace, democracy and development, resistance denies this claim by pointing to the hypocrisy of power, to other possible agendas and to the lack of commitment to peacebuilding's own discourse. Mockery, denigration and slandering are hidden transcripts. They run beneath official proclamations, challenging, or at least contrasting with, the image of unanimity that authorities wish to project in regard to their actions.

\section{Mockery}

Mockery reflects a critique in which politicians, MONUC/MONUSCO and authorities in general are pictured as lazy and corrupt. This practice constitutes a pattern. Any visitor to the DRC can identify how the MONUC/MONUSCO is mocked, almost to the extent of arguing that it is thanks to the Congolese people that UN officers have a job. For example, at the peak of violence by renegade soldier Nkunda a popular saying against MONUC was: 'no Nkunda, no job' (ExMONUC Officer (no. 2) 2010; Group Jeremie Representative 1 2009; Group Jeremie Representative 2 2010; MONUC Civil Affairs Officer (no. 1) 2009; 
MONUC Civil Affairs Officer (no. 14) 2009). ${ }^{5}$ This inferred that MONUC needed seemingly artificial justifications for being in the country. It was not that the threat from Nkunda was not real, but that people saw the emergence of the likes of Nkunda as a consequence of MONUC's not doing its job properly, thus perpetuating the need for the mission to be there.

This was already the case with the initial deployment of MONUC. The authorisation of MONUC as an observation mission ${ }^{6}$ prompted people to state: 'its name says everything, they are just here to observe how we are killed' (AFEPADE 2010; Bukavu Resident 2010; COJESKI 2010; Masudi 2009). The 'they do nothing' criticism has not stopped, and it is not uncommon to hear people complaining 'they just run up and down [in] their cars' or inquiring "what do they do?"7 The criticism is made from lived experience, illustrating how the popular classes see themselves as bearing the suffering that arises from the shortcomings of the decisions and strategies of power. From this criticism it is possible to observe an articulation of 'what should be happening', or 'what MONUC should be doing'. In Kinshasa, the same day that MONUC changed to MONUSCO, with a change of mandate, the mission was renamed 'MONUSKOL' (as in the beer Skol, portraying a vision of UN workers as more interested in alcohol and night-life than in peace) (MONUSCO Electoral Division Officer 2010). ${ }^{8}$ In Bunyakiri and Bukavu, MONUC or MONUSCO were said to be abbreviations for 'Milice Onusienne au Congo' (UN Militia in Congo) (Bukavu Resident 2010; Demobilised Mai Mai Padiri Combatant 2 2010; Femmes Père SaintSimon Representative 2010; Focus Group Young People Bunyakiri 2010; Group Jeremie Representative 1 2009). This not only refers to the multiplicity of armed groups that the UN and the government cannot stop, but also to a common criticism levelled at the UN that it is not there to make peace.

Criticism not only follows an international/local divide, but represents several imaginaries of authorities and subordinates. The president and the Government are not exempt from mockery. Joseph Kabila is called 'Kinyago' (marionette) or 'Kanambe', implying that he has 'Rwandese origins'. 9 Portraying Kabila as manipulated to serve external agendas or denying his Congolese nationality is a direct challenge to his legitimacy. A flipside of nicknames is the technique of refusing to say Kabila's name. Kabila becomes 'that one', 'him' or 'the one you know'. Although this could represent voting preferences, it is striking that this is consistently observable in Kinshasa, the two Kivus and Equateur. ${ }^{10}$ This silence seems to be both a protest and a defence, which simultaneously deny and mitigate authority. ${ }^{11}$

In addition to nicknames and silences, jokes are a common way to mock the Government. For instance, very soon after the Government committed to its 'five pledges', people renamed them the 'five songs', effectively portraying the Government as not being serious in their realisation. ${ }^{12}$ In Goma, a common joke asks 'what has changed?' and people respond, 'well, BunaZa [Zaire's beer] is now 
BunaCo [Congo's beer] and the market CadeZa now it is called CadeCo'. The joke implies that nothing substantial has changed and people continue to experience hardship.

Justice is one of the domains in which there have been fewer improvements (EU PAG Representative; Trefon 2011: 14; UN Secretary General Ban Ki-Moon 2012: paras 57 and 81; UN Security Council 2012: paras 8-9 and 12; Vircoulon 2009: 87-102). It is also a site of mockery and critique. ${ }^{13}$ An evaluation study of UN Development Programme activities in 2006 asserts that 'the justice system is [...] distrusted and reputed to be corrupt' (Faubert 2006: 9). In the study, 'most respondents stated that they would rather put their trust in institutions such as churches and human rights organizations or proximity community leaders' (Faubert 2006: 9). ${ }^{14}$ During the 2006 election campaign Kabila promised to reform the justice sector through the slogan 'the doors of prison are big' (Kayembe 2006). For Kabila this statement conveyed his Government's commitment to 'zero tolerance' against corruption and to prosecuting crimes, no matter who was responsible. As corruption is seen as one of the biggest obstacles to conflict resolution and access to justice, people added a simple sentence to the slogan to change its meaning. The slogan then read: "the doors of the prison are big, to take all the big thieves out'. ${ }^{15}$ The expression was a critique of the lack of justice, in particular of the impunity of those who commit the major crimes (UPDI Representative 2010; Participant Observation III 2009). This slogan was reflected in many forms and shapes in Bukavu, and in other cities and territories. A Group Jeremie representative complained that 'one could go to prison for stealing a chicken while big thieves are out' (Group Jeremie Representative 1 2009). In Bunyakiri, where a prison had just been built next to an almost-ruined hospital, one of the doctors complained that the prison would be just for 'the poor', while the real thieves enjoyed 'the benefit of power' (Informal Conversation Bunyakiri Hospital Doctor 2010).

This mockery expresses in humour what otherwise is a violent experience. As seen in the previous chapter, the military strategies that have taken place under the programmes of Umoja Wetu, Kimya II and Amani Leo have succeeded to a certain extent in demobilising thousands of combatants. But this has come at a high price for the civilian population. People in local villages not only have to host and feed soldiers with special privileges under these operations, but also to take care of the daily needs of demobilised soldiers deployed in the villages without resources for their reintegration into civil life. Those combatants that join the army or the national police are also likely to keep settling ethnic rivalries while living off the population, not least because of a lack of salary payment (Global Witness 2009: 16-17). Further, issues of land, housing and ethnic rivalries brought by the return of refugees and internally displaced persons (IDPs) are left for the villagers to deal with. As such, when people on the ground mock the programme ‘Amani Leo’ (Peace Today), calling it ‘Amani Kesho’ (Peace 
Tomorrow), this reflects an underlying reality of armed conflict, poverty and impunity.

\section{Denigration, slandering and 'radio trottoir'"16}

A less humorous way to de-legitimise and criticise the actions of both the Government and MONUC/MONUSCO is through rumours and insults. Whether about particular politicians, blue helmets or, in general, MONUC/MONUSCO and the Government, rumours portray them as purposely continuing the conflict or trafficking with resources. In Bunyakiri, for example, many residents believed that MONUSCO was giving food and clothes to the FDLR. ${ }^{17}$ The story was developed in more detail in a focus group held with young people of the town. One of the participants stated: 'Not long ago one FARDC shot a FDLR, and when they were going to recuperate the body, he was dressed with the MONUC uniform and had biscuits and even the shoes of MONUC' (Focus Group Young People Bunyakiri 2010). When this story was put to a MONUSCO official, she responded by acknowledging that such rumours are commonplace and that the problem is that 'there is not good public information' (MONUSCO Civil Affairs Officer (no. 145) 2010). These rumours are, for MONUC/MONUSCO officers, evidence of the manipulation of politicians; ${ }^{18}$ yet what they show is that people are not willing to see MONUSCO in a positive light. Rumour resonates with a deeper political agenda. Whether these stories are true or not, whether they originate from a specific politician's agenda or even FARDC, they are used to discredit MONUSCO. ${ }^{19}$ They are a symbol of social conflict and dissent.

The Government and opposition leaders are not absent in this. As seen above, Kabila is accused of working for Rwanda's benefit. In Baraka, some Fizi deputies are accused of arming Yakutumba both from an ideological perspective and also as a way to access mineral resources. ${ }^{20}$ It is striking that in a stretch of about $800 \mathrm{~km}$ between Fizi and Beni and of over 3,000 km between these locations and Kinshasa, in a country with hardly any communications and road network, and consistently over five years of field research, the same rumours are found word for word: 'The FDLR is an invention to continue the war', or 'UN's soldiers traffic with coltan'. ${ }^{21}$ Some of these rumours have become part of the mainstream discourse: 'the UN is there to serve Rwandan interests' or 'UK, US and Rwanda want the balkanization of Congo' (Monsa Iyaka 2009; Radio Okapi 2006, 2012b). In Bunyakiri, Fizi and Masisi, for example, a similar rumour circulated: MONUSCO provided FDLR elements with uniforms, weapons and food to sustain a war in Congo in order to keep Congo weak and easily exploitable. It is remarkable that inquiries about these rumours demonstrate that they rarely come from first-hand experiences and that acquiring details highlights contradictions in the facts. Rumour is used to deny the benign purpose of peace and state-builders, their authority and rhetoric. 
Although rumours are widely known, they remain something to be commented on in the quiet. Denigration through insults also takes place this way. The words of the union representative that open this chapter were followed by a more direct statement: 'yes, you can do the parade and the show and everyone might give you a big round of applause, but it is to mock you, inside they are saying "so, yes, you come again to piss us off"' (Peasant Union Representative (no. 151) 2010). The catalogue of insults is extensive. It tags politicians and international agents as 'traffickers', 'murderers', 'thieves', 'lazy' and 'liars', amongst others. ${ }^{22}$ As Scott noted, insults should be seen as a more direct act of resistance, even if they do not confront authorities face to face and remain as part of the hidden transcript.

Portraying international and national political actors as incapable, greedy, hypocritical and anti-democratic is a form of discursive resistance that denies the claim of legitimacy and consent. It is a form of de-legitimation, and hence of more intentional (claim-regarding) resistance, even if people would not necessarily label these acts as such. What this means is that the intent of mocking and slandering authorities is, precisely, mocking and slandering authorities. The intent, in other words, cannot be inferred beyond the act. It is reasonable to assume from here that actors are aware of the fact that they are, at least to a certain extent, targeting the deference, credibility, respectability and reputation of authority. These forms of discursive resistance have embedded a political critique of peacebuilding strategies and agenda advancement. In mocking or portraying a negative image of the state of current affairs, these forms of resistance carry out an idea of how reality should be.

\section{Ideals and the articulation of social justice as agenda advancing}

Going back to how claims of authority are justified on the basis of long-term idealised promises, this final section analyses how these promises become a platform from which to launch a critique of authority, hold it to account and articulate aspirations for social justice. This is done by rearticulating the official peacebuilding discourse. Although everyday resistance is not always underpinned by these ideas and may be motivated by more banal and immediate goals, these redefinitions are an important insight into prevalent political aspirations and underpin many other practices that will be explored in the next chapters.

\section{The good state}

The state is a primary example of the dynamics of denial and subversion. Against the critique and discourses seen above, the state becomes rearticulated as something like a 'good king'. For a Caritas representative, 'the state doesn't exist, it doesn't protect people, its services are taken over by NGOs and its role must be 
that of distributing wealth' (Caritas Representative, Justice and Peace Commission, Goma 2009). ${ }^{23}$ A Union Paysanne pour le Developpement Integral (UPDI) representative believed that the state should be there to guarantee a good standard of living for the peasants and provide the same protection to agriculture as in Europe (UPDI Representative 2010). The so-called 'government of national unity' brought in by the 2002 Sun City agreements, was renamed ' $1+4=0$ '. As in the most idealised versions of what the state can and should do, seen in the World Bank and OEDC reports in earlier chapters, or what Chandler calls the 'silver bullet', the state is redefined also in non-elite discourses as the engine for development, peace, well-being and public service. The creation of an ideal picture of the state as something like a 'good king' or a 'prophet' is a form of resistance against the lived reality.

In the DRC, idealising the state as a saviour is not new. However, as Englebert notes:

Congolese identity, the imagination of Congo and of the Congolese nation, serve as ideological foundation for the reproduction of the state, denying legitimacy to alternative scenarios and confining political action to factionalism for control of the state itself, or to the non-threatening realm of 'civil society'. (2002: 592)

Englebert notes that the co-idealisation of the Congolese nation both as resistance against domination and as its reproduction is a discursive battleground in which elites finally take the upper hand. Yet the significance of the critique, which operates as a way to hold decision-makers to account, and the political aspirations it simultaneously projects are not to be disregarded. An image of a good chief is projected onto the state, resulting in an inversion of terms, where state authority is legitimised in so far as it serves the most vulnerable. Similarly, the image constructed of what the state should be becomes a mirror of what subordinate groups wish the state would provide for them. As such, what Congolese subordinate classes seem to be waiting for is an ideal that does not exist in any country in the world. They paint a picture of leaders that are caring and honest, delivering the services the population needs, respecting the law and protecting citizens. ${ }^{24}$ The idealised state as a public service and providing social well-being is counterposed to an experience of the state as dominating, coercive and extractive. Agendas of political participation, development and peace are inextricably attached to it.

\section{Democracy or 'démon-cracy"25}

Against a practice of democracy that is almost exclusively premised on the organisation of presidential and national elections, democracy for non-elites is premised on direct participation in decision-making processes. In a workshop for secondary school students on 'participatory governance' organised by the 
Group Jeremie in Bukavu, it became clear that even if 'participatory governance' sounded as if it had just been taken from any policy report from the UN Department of Political Affairs, it had been appropriated to mean that people should participate directly in the decision-making processes of the country (Participant Observation III 2009). This included a vision in which people had a say in the management of the country's resources and their distribution. An NGO representative made this point clearly:

The state lives now on the shoulders of people, their agents do not get paid ... the problem here in the DRC is that democracy is also badly distributed. We should have started by local elections ... but we have started by the presidential elections, legislatives, then provincial, and they have stopped there, and from there they take what they need, they share power amongst themselves, they take whatever land they need, without taking care of their real responsibilities (ADDF Representative 2010). ${ }^{26}$

This representative is arguing that having started with local elections rather than national would have provided greater accountability and political control, and would have solved the institutional problems linked to problems of development. While there is a critique of how democracy works at the moment, democracy is being redefined as actual participation by the citizenry.

These criticisms are prevalent and have been present at different landmarks in the transition after the wars. At the time of the Inter-Congolese Dialogue (2002) the demand to participate in negotiations for peace meant that peace and democracy had to involve all sectors of society. However, many groups participating in this event argued that, in the end, the process only facilitated a dialogue between the Government and the MLC (Irin News 2002). As such, at the time of the 23 March Agreement in 2009, which put an end to the uprising of CNDP (Nkunda) and other armed groups such as PARECO, people complained that what was being created was an incentive to take up arms, raid the population and then partake in government (Femmes Père Saint-Simon Representative 2010; Ngemulo 2010). The negotiations included that these groups would become political parties and would have the opportunity to partake in power (Programme Amani Leo 2009). Notwithstanding the complexity and challenges of ending armed conflict, these discourses are challenging the legitimacy of the actors who partake in government and redefining this version of 'peace' as a truce of warlords.

\section{Development}

Participation is also a prominent theme in the critique of how development (and extraction and exploitation) takes place. As such, alongside the criticism that wealth stays 'in the pockets of the politicians' and that the real wealth of the country goes elsewhere, there is the idea that development aid does not arrive 


\section{Claims to authority and discursive attacks}

and that for development to be properly carried out, and not just from aid agencies, people in the lowest ranks of society have to be involved. This was articulated most forcefully by a representative of a peasant cooperative in Bukavu. ${ }^{27}$ Since the mid-1990s the co-operative had felt the logic of development was marginalising and disempowering them, something that they continue to see presently. The representative stated:

We realised that those organisations hadn't changed much, they are within a logic of experts, so much a logic of experts that they have forgotten to engage the beneficiaries of their projects. So our members did not see themselves in those projects, they do them for us, without us? ... that's against us! So we wondered, would it not be possible to express and do things by ourselves? (Peasant Union Member (no. 151) 2010).

The logic behind the creation of their organisation was a belief in the need to engage more fully in the processes of development in order for development to be effective. This has been a constant in the way development projects are read. A women's NGO representative in Butembo also regretted the approach of certain INGOs (that she did not wish to cite), affirming that instead of supporting us, they replaced us ... They execute projects, without engaging the population or the local NGOs' (ADDF Representative 2010). ${ }^{28}$ This participation is a way of expressing that development has to contain a democratic element. Democratising resources means that they are equally distributed amongst the population and that there is direct control over the distribution and use of these resources (Kajemba 2009).

\section{Peace}

Peace, the final element of the statebuilding discourse is one of the most ambiguous and multifaceted. Whether it is used to criticise the shortcomings of peacebuilding strategies or to argue that they have succeeded, peace is defined in multiple ways - with each meaning signalling a different political agenda. Autesserre (2009), for instance, has demonstrated how international actors, including international organisations, diplomatic missions and INGOs view Congo as innately violent. This assumption has resulted in peace being seen as a return to normality, where violence was still present (Autesserre 2009: 251). However, this is not only an issue for international elites. For Programme Amani, 'peace is a very long process' (Programme Amani Leo 2009: 2); and they are clear that 'the war is over' (STAREC - Amani Leo Representative 2009). This long process is, however, settled at the top and experienced at the bottom. The vision of non-war/peacebuilding resonates with non-elites' critique of the peacebuilding strategies, in which peace is about the signature of a 'peace agreement' and 'power-sharing'. Defining peace therefore sets the priorities and 
strategies to be undertaken. For those who are still confronting armed groups, violence, poverty, repression and absence of basic services, speaking of peace is simultaneously a critique and the voicing of what could be seen as an articulation of social justice. Peace is redefined as being both a process and a product of political participation, development and personal and collective well-being. What to do about it and how to set priorities is a matter of putting non-elite agendas at the forefront and of having access to decision-making processes. In this spirit, a Group Jeremie representative stated:

We must start from the proposals that are made at the grassroots. What we want and what the international community wants is diametrically opposed. I am from Kinshasa, here in Kinshasa things don't go, people suffer. Peace has multiple dimensions: social, environmental, economic ... We are oppressed, exterminated, our women are raped, the children abducted by the military ... The peace in Congo is a global thing, we need a global approach and not a sectored approach like the MONUC does. It reforms the justice sector here, it does democracy promotion there ... Peace here is less important than money. The Congolese context is unique ... But you, the internationals, you come here with laboratory theories, preconceived models and try to impose them on the Congo. No, that is not peace. (Group Jeremie Representative 1 2009)

The 'diametrical opposition' that this interviewee is referring to seems to point fundamentally to how peacebuilding is undertaken. Most likely the 'international community', as he states, would agree that peace has all of those dimensions. What he is pointing out is that the strategies enacted are not conducive to addressing all of those dimensions, and that, contrary to the discourses of peace, 'money' is the underlying real motivation. This is representative of similar responses gathered. As an indication, the representatives of all 31 noninternationally funded NGOs who were interviewed denied living in a 'postconflict' or non-war context, linking 'real peace' to well-being and political participation. Additionally and simultaneously, an alternative agenda is being drafted that redefines peace as social justice with multiple dimensions.

\section{Subverting discourses}

Shared vocabulary does not mean shared meanings. The fact that authority claims are made as idealised promises offers a fertile ground on which to hold authority to account. As Scott notes:

Perhaps the greatest problem with the concept of hegemony is the implicit assumption that the ideological incorporation of subordinate groups will necessarily diminish social conflict. And yet, we know that any ideology which makes a claim to hegemony must, in effect, make promises to subordinate groups by way of explaining why a particular social order is also in their best interests. Once such promises are extended, the way is open to conflict. (1990: 77) 


\section{Claims to authority and discursive attacks}

Peacebuilding, and the reconstruction of state authority at the heart of it, is deployed as a moral necessity to which subordinate classes need to consent, wait and suffer the consequences, for this will benefit people in the long run. Yet, the same promises are taken literally, holding power to account, confronting the ideal that peacebuilding paints against the reality on the ground. This is not a new critique. Paul Gilroy, for example, has analysed how black music has provided a way to confront reality and voice aspirations. He argues that:

The politics of fulfilment practised by the descendants of slaves demands that bourgeois civil society lives up to the promises of its own rhetoric and offers a means whereby demands for justice, rational organization of the productive processes, etc, can be expressed. (Gilroy 1993: 134)

These are not necessarily found overtly but, rather, as a hidden transcript. Or, as Gilroy puts it, by 'opaque means':

Created under the nose of the overseer, the utopian desires which fuel the politics of transfiguration must be invoked by other deliberately opaque means. This politics exists on a lower frequency where it is played, danced and acted, as well as sung about. (1993: 134)

The inversion of peacebuilding's vocabulary, as discussed above, illustrates ways in which it is de-legitimised, critiqued, held to account and counterreacted with the articulation of how things should be. The 'subtle' difference in meaning, as Toulabor notes, 'consists, grosso modo, in doubling the usual or conventional sense of the words in giving them second semi-hermetic meanings' (2008: 99). The state becomes a 'good king' with the capacity for salvation that effectively works for the poor; democracy means direct participation in the decision-making processes at all levels; development means wealth distribution and access to its management; and peace encompasses a sense of tranquillity, free from threats of violence and linked to a sense of justice. They are a transformation of power's own idealisation of its capacities, together with the political aspirations of subordinate classes. The creation of ideals represents not only the negation of the present order, but also the formulation of an alternative one.

\section{Conclusion}

In the DRC there is no social-political movement that resists peacebuilding. Rather, there is a consistent pattern of acts that challenge the actions and inactions of national and international elites and that attempt to mitigate the experience of a predatory violent order. At the discursive level, this entails contrasting lived experience to the promises of the state as rightful authority and service provider. While this image of the state is not being rejected as an ideal, it is rejected in practice. Elite discourses imply a morality that lays a claim to 
legitimate authority, while exempting elites from responsibility for failure. For non-elites, discourses are ways of voicing discontent while remaining pragmatic about both possibilities and repression; they are relevant because they are part of a shared critique. The fact that these discourses are found everywhere and resonate across a broad construct of 'Congolese identity' and 'Congolese nation' indicates how everyday resistance operates as a covert strategy, attempting to escape repression while mitigating its effects.

What this chapter has illustrated, beyond how the discursive arena is fertile ground for everyday resistance, is the ambivalence of these discourses as platforms on which both domination and resistance operate. In Scottian terms, peacebuilding creates public and hidden transcripts where rhetoric, image and expected behaviour are enacted for different audiences, following a shared vocabulary, including that of state authority, democracy, development and peace. The relationship of different actors to these ideals is enacted as a 'pose'; that is, there is a level of ambiguity in how public images of authority, deference and obedience are exercised. Discourses are significant because statebuilding strategies are established and justified as a form of inevitable good. The moral authority of the good state and its subsequent delivery of peace, democracy and development facilitate a way to justify a reality of war, poverty and impunity. As such, an obvious starting point from which to look for resistance is the idealism on which promises are made. These powerful promises seem to be enough to request the population to keep waiting, obeying, paying taxes, providing for themselves and facing repression in return for raising concerns.

The implication is that peacebuilding's discourse rests on people's aspirations, and not the other way around. To this extent, peacebuilding is hardly Western or liberal, but is better seen as an example of the discursive practice of authority, and more as a populist discourse. Demands to participate in the decision-making processes, to be protected, to be heard and to enjoy the wealth of their own country are seemingly modest demands. However, these demands are idealised in such a way that they pose a fundamental challenge to peacebuilding practices. In a context of limited capacities for political action, the discursive is a fruitful site of resistance, although not the only one. The following chapters will complement many of the discourses surveyed in this one. The hidden transcript runs through Mai Mai militias, justifications for tax evasion and in the undertaking of a myriad of creative survival strategies. Underlying these tactics is a process of de-legitimisation, of advancing alternative agendas and raising political aspirations. These discourses and the political alternatives embedded within them are realised not just in mechanisms of critique and the voicing of aspirations, but in the processes of denial and mitigation undertaken for navigating a context of violence and poverty. 


\section{Claims to authority and discursive attacks}

\section{Notes}

1 Applying a similar argument to aid agencies operating in countries in conflict, and the DRC in particular, Zoe Marriage (2006) argues that these agencies justify their actions under a moral authority, which simultaneously allows them to externalise blame onto recipients for the shortcomings of their own activities.

2 The example of the quietness in the classroom in comparison to the burst of talking when the teacher leaves illustrates the point (Scott 1990: 25).

3 This sentiment was recorded amongst all UN officers interviewed.

4 This was explicit in 90 per cent of the interviews with MONUSCO officials between 2009 and 2014.

5 Valeria Izzi (2011) argues that this sort of slandering illustrates mistrust and the obstacles for the work of peacebuilders.

6 MONUC was placed under Chapter VII by Resolution 1291 in 2000, but not in its original authorisation in 1999. MONUC/MONUSCO has not tended to use force overall. See Chapter 3.

7 Although this was raised in many interviews, the sentiment reflected here is something observed as prevalent in all fieldwork locations in ordinary interactions outside interviews.

8 This was corroborated in daily outgoings in Kinshasa, and echoed in several interviews and informal conversations elsewhere (Ex-MONUC Officer (no. 2) 2010; Informal Conversation International Alert Research Assistant 2010; MONUSCO Officer (no. 190) 2014).

9 Those who assert that Kabila is Rwandese say that his real name is Hipolite Kanambe and not Joseph Kabila Kabange.

10 This was observed during fieldwork in Kinshasa, in North and South Kivu and in Equateur as an electoral observer from September to December 2011.

11 The use of silence as sabotage is not a new nor an uncommon practice of resistance in Africa (Abbink et al. 2008: 17).

12 In French from the 'cinq chantiers' to the 'cinq chansons'. For the programme visit President Joseph Kabila Office (2009).

13 Direct mockery of the justice system was recorded in 10 interviews with subordinate groups/civil society representatives. That there is a sentiment of distrust in the justice system in Congolese society was directly raised in all interviews with civil society/ordinary people and four Government officials speaking of a popular sentiment.

14 There are several organisations, now funded by INGOs, that do justice settlements as a way to avoid having to go to the courts, e.g. Life and Peace Institute and Alliance pour la Paix et la Concorde.

15 This was brought up explicitly in five interviews: Group Jeremie Representative 1 (2009); Group Jeremie Representative 2 (2010); UPDI Representative (2010); Nyiragongo SOCICO Representative (2014); Youth NGO representative (2014). It also resonated in many of the student groups organised to speak of corruption and justice in College Alfajiri, Bukavu (Participant Observation III 2009) and in two focus groups with women in Bunyakiri (2010) and Kamituga (2014). References to double standards in applying the law and to experiences of repression also came up in several interviews (COJESKI 2010; CODHOD Representative 2009; Observatoire des Droits de l'Homme et Contre la Torture 2009; UniKin Student Union Representative, Kinshasa 2009).

16 Rumour in French. 
17 Brought up in the two focus groups held in Bunyakiri. Interviews with four Bunyakiribased NGOs confirmed that these were common rumours: Alliance pour la Paix et la Concorde, Association de Dèfense de Droits l'Homme Bunyaki, Voix Sans Voix and Femmes Père Saint Simon. It was also raised by Imam of the Islamic Community in Bunyakiri (Kabambi 2010).

18 Half of MONUC/MONUSCO officers interviewed directly made reference to this issue.

19 E.g. Bemba's 2006 campaign '100 per cent Congolais' reflected the rumour that Kabila was Rwandese. Also in the latest reports on the 2011 elections both the Carter Centre Electoral observation missions point out that politicians tended to spread hatred discourses and slandering as a political weapon (Carter Center 2012: 71 and 97).

20 The veracity of the rumour could not be ascertained but several interviewees confirmed that this was an extended belief in Baraka (Fizi SOCICO Representative 2010; Human Rights NGO Representative (no. 127) 2010).

21 For example, similar rumours to those in Bunyakiri were expressed by residents of Masisi who specified that 'In Nyabiondo and Pinga the Indian contingent has profiteered of mineral resources' (Informal Conversation with Masisi Parish Priest 2010).

22 This was gathered most significantly in informal conversations. The words of an airport porter are revealing: 'Here everyone comes, take what they want, the politicians are liars, the state is a thief and the MONUC does nothing, they are accomplices in all this' (Informal Conversation with Airport Worker - Luggage Porter 2009).

23 Similar statements were repeated in multiple interviews. For example: 'There is no state here, no roads, no water, no free education [...] Those are the real problems and in order to address them, they need to start identifying the local initiatives that are already in place [but] we are replaced by everyone' (Pole Institute Researcher 2010).

24 All interviews with members of civil society and non-elite participants made a link between the state and its responsibility for security.

25 A form of mocking of democracy around Kinshasa (Yoka 2009: 250).

26 Other similar statements were as follows: 'the resources, minerals, forestry, water, etc, have to be distributed equally amongst the population' (Kajemba 2009); 'The population must participate in how the public economic resources are distributed', from the summary of a group of students in High School Workshop (Participant Observation III 2009); 'Resources must be available for the population to live not for the politicians to enrich themselves' (Focus Group Civil Society Mwenga 2014).

27 Other interviewees made the same point (ADDF Representative 2010; Group Jeremie Representative 2 2010; Pole Institute Researcher 2010; SPIP Representative 2011).

28 They have accessed International Alert funds. 